\title{
LESSON 27
}

MARGINS: Pica, 20-70; Elite, Type this paragraph as many times as your teacher asks.

$30-80$

Warm up

Clinic

Repeated letters

Carriage return practice

Increase Speed

30 wpm 1 minute.

S9 - SI 1.03

$\mathrm{S} 10-\mathrm{SI} 1.03$

Improve Accuracy

25 wpm 1 minute.

$A 6-S I 1.36$

A7 - SI 1.40

Test your Skill

1 minute.

T3 - SI 1.14
1.

The drive was very exciting as both cars went flat out across the frozen lake to join the party. It was quite madly stimulating.

If you find that the second of the repeated letters in words is typed too faintly, practise each line of this exercise 3 times and try to type the second letter slightly harder than the first.

2. book full tool jaffa weed sill veer lass fuss pipp

3. bibb noon hagg seen ebb accept boob mass fizz coop

4. ruff rudd penny mill keep hall gill feet eddy cell

If your left-hand margin is uneven, type this drill just as it is 3 times. Return the carriage smartly with the left hand, keeping the right hand over the home keys ready to start typing.

5. If you return

6. If you return the carriage

7. If you return the carriage as instructed

8. Try to return the carriage as smartly as possible.

It was so wet that they could not go for Paul and John as they said they would. They were all a little sad at the thought that they would miss the walk.

The car would not start and he could see that he would miss most of the match unless he could be at the bus stop in time. It was a long run but he did it.

Extra power produced by the additional superlarge motor made the go-cart easily the quickest a fan could wish to see or drive.

Ivan's new camera was the best in the store's cinema department. Most friends were most anxious to examine it very carefully.

The wind blew hard all that week and the boat 9 raced across the ocean in record time. It was not 19 long before the news rang out that they had docked 29 and crowds of people came to see them land. Frank 39 was glad it was over:

How many spaces do you leave after a question mark?

How many spaces do you leave after a colon?

How many spaces do you leave after a person's initials? 